\title{
PENTINGNYA PENDIDIKAN KARAKTER DAN BUDI PEKERTI DI SEKOLAH PADA ERA GLOBALISASI
}

\author{
Abd. Latif Samal \\ Institut Agama Islam Negeri IAIN Manado \\ abdulatif102@gmail.com
}

\begin{abstract}
The view that the values adhered to determine a person's behavior is usually in sociology called the Weberian school. One of the supporters of this school is Talcott Parsos, who introduced the theory of action which says that human action is influenced first by a cultural system consisting of values and rules that are adopted and the knowledge and customs they have. Schools as learning institutions instill values, shape human beings who have character and virtue through teaching. The character education program will succeed in school, if all personalities in the school can work together with parents of students, so that the educational goals expected by this nation can truly be felt, and can touch the positive values of the nation's children who are expected to be together.
\end{abstract}

Keywords: Tangent Point, Competence, General Justice, State Administrative Courts, Absolute Competence.

Abstrak. Pandangan bahwa nilai yang dianut menentukan tingkah laku seseorang ini biasanya dalam ilmu sosiologi disebut aliran Weberian. Salah satu pendukung aliran ini bernama Talcott Parsos, yang memperkenalkan theory of action atau teori tindakan yang mengatakan bahwa tindakan manusia itu dipengaruhi pertama-tama oleh sistem budaya yang terdiri atas nilai dan aturan hukum yang dianut serta pengetahuan dan adat istiadat yang dimilikinya. Sekolah sebagai lembaga pembelajaran menanamkan nilainilai, membentuk manusia yang berkarakter dan berbudi luhur lewat mengajar. Program pendidikan karakter akan berhasil di sekolah, apabila semua personal di sekolah dapat bekerjasama dengan orang tua siswa, sehingga tujuan pendidikan yang diharapkan oleh bangsa ini benar-benar dapat dirasakan, dan dapat menyentuh nilai-nilai positif dari anak bangsa yang diharapkan bersama.

Keywords: Titik Singgung, Kompetensi, Peradilan Umum, Peradilan Tata Usaha Negara, Kompetensi Absolut. 


\section{Pendahuluan}

Karakter itu pada dasarnya adalah bangunan nilai baik dan buruk yang telah menginternalisasi pada diri seseorang, dan menjadi standar atau Code of conduct-nyamaka mempengaruhi segala tindakannya. Pandangan bahwa nilai yang dianut menentukan tingkah laku seseorang ini biasanya dalam ilmu sosiologi disebut aliranWeberian.Salah satu pendukung aliran ini bernama Talcott Parsos, yang memperkenalkan theory of action atau teori tindakan yang mengatakan bahwatindakan manusia itu dipengaruhi pertama-tama oleh sistem budaya yang terdiri atas nilai dan aturan hukum yang dianut serta pengetahuan dan adat istiadat yangdimilikinya. ${ }^{1}$

Sistem budaya ini selanjutnya dipengaruhi oleh sistem sosial, sistem kepibadian, dan sistem organisma. Sebaiknya sistem organisma mendukung sistem kepribadian, sistem sosial dan akhirnya sistem budaya. Hubungan pengaruh mempengaruhi dan saling mendukung itu terjadi dalam konteks lingkungan tertentu.Inilah kira-kira taksonomi dari setiap tindakan manusia. Dalam hal ini karakter sebagai nilai yang berada pada diri seorang siswa khususnya bila berada di sekolah, haruslah mendasari dan menjiwai seluruh tindakan dari seorang siswa.

\section{Permasalahan}

Melihat fenomena yang terjadi akhirakhir ini di dunia pendidikan dengan lajunya arus informasi dan globalisasi yang melanda dunia pada umumnya, nilainilai budaya karakter dan nilai kesopanan di sekolah sudah sangat ironis.Misalnya siswasering membantah guru, tidak menghormati guru, bahkan ada siswa yang mengajakgurunya untuk adu otot.Hal

1 Dirjen Pendidikan Kemendiknas RI, 2010. Pendidikan Karakter. ini membuktikan bahwa nilai-nilai budaya kesopanan ataubudi pekerti di sekolah sudah mulai hilang.

Kita bisa membandingkan di era 7080 an pendidikan karakter atau budipekerti di sekolah diutamakan sehingga siswa sangat menghormati guru bahkan takutkalau siswa dimarahi guru karena bersalah dan tidak pernah terdengar kalau ada tawuran antara siswa di sekolah sendiri maupun dengan sekolah lain, begitu juga tidakpemah ada siswa menganiaya guru begitu juga sebaliknya, karena pendidikan karakteratau pendidikan budi pekerti di sekolah dijalankan berdasarkan hati nurani tidak dengan keterpaksaan.

Amanat yang tertuang dalam Undang-Undang Nomor 20 Tahun 2003 tentangSistem Pendidikan Nasional, dalam pasal 3 dinyatakan bahwa pendidikan nasionalberfungsi mengembangkan kemampuan dan membentuk watak serta peradaban bangsayang bermartabat dalam rangka mencerdaskan bangsa. Selanjutnya ditegaskan bahwa pendidikan nasional bertujuan mengembangkan potensi peserta didik menjadi manusia yang beriman dan bertakwa kepada Tuhan yang Maha Esa, berakhlak mulia, sehat, berilmu, cakap, mandiri, dan menjadi warga Negara yang demokrasi serta bertanggungjawab. ${ }^{2}$ Tujuan pendidikan nasional tersebut mengisyaratkan bahwa melalui pendidikan hendak diwujudkan peserta didik yang memiliki berbagai kecerdasan, baik kecerdasan spiritual, emosional, sosial, intelektual maupun kecerdasan kinestika.

Pendidikan nasional mempunyai visi dan misi yang mulia mission and vision sarceterhadap individu peserta didik, yaitu membangun pribadi yang memiliki

2 Undang-Undang No. 20 Tahun 2003, Sistem Pendidikan Nasional 
ilmu pengetahuan, meningkatkan kemampuan teknis, mengembangkan kepribadian yangkokoh dan membentuk karalter yang kuat.

Terbentuknya karakter peserta didik yang kuat dan kokoh diyakini merupakanhal penting dan mutlak dimiliki peserta didik untuk menghadapi tantangan hidup dimasa-masa akan datang. Pengembangan karakter yang diperoleh melalui pendidikan;baik ditingkat sekolah maupun pendidikan tinggi, dapat mendorong mereka menjadianak-anak bangsa yang memiliki kepribadian yang unggul seperti diharapkan dalamtujuan pendidikan nasional.Berbagai upaya telah dilahkan untuk menjadikan pendidikan lebih mempunyai makna bagi individu yang tidak sekedar memberipengetahuan pada tataran kognitif; tetapi juga menyentuh tatarun afektif dan kognitif,seperti yang termasuk dalam mata pelajaran yang berwawasan pembinaan kepribadian, pendidikan kewarganegaraan, pendidikan bahasa Indonesia. Namun demikian, mengingat kondisi dan zaman yang berubah dengan cepat, maka upaya-upaya yang sudah ada tersebut perlu diperluas dan dikemas kembali dalam wadah yang lebihkomprehensif dan lebih bermakna.

\section{Strategi Pendidikan Karakter/ Pendidikan Budi Pekerti}

Undang-undang Nomor 2 Tahun 1989 maupun undang-Undang Nomor 20Tahun 2003 tentang Sistem Pendidikan Nasional secara eksplisit menyatakan bahwatujuan pendidikan nasional, antara lain beriman, bertaqwa dan berbudi pekerti luhur. Kenyataan menunjukkan bahwa akhlak atau budi pekerti siswa terutama di kotakotabesar sangat memprihatinkan seperti merebaknya tawuran, narkoba, tindak kekerasandan pelanggaran sopao santun.Kenyataan sosial menuqiukkan bahwa budipekerti/karakter seperti sopan santun, kemampuan untuk saling menghormati dansebagainya kurang terlihat dalam kehidupan masyarakat sehingga banyak orang tuamerasa khawatir apabila dikemudian hari nilainilai luhur yang dimiliki bangsa kita,termasuk nilai-nilai dalam keluarga.

Tantangan era globalisasi dengan arus informasi yang dahsyat melalui media elektronika dan media cetak sebagai sarat dengan muatan nilai yang bertentangan dengan kepribadian nasional.Hal ini sangat berpengaruh negatif terhadap perkembangan pola pikir dan perilaku generasi muda bangsa, khususnya para pelajar kita.

Secara kontektual dewasa ini marak tayangan media cetak yang memuat fenomena dan kasus perseteruan dalam berbagai kalangan yang memberi kesanseakan-akan bangsa kita sedang mengalami krisis etika dan krisis kepercayaan diriyang berkepanjangan. Pendidikan karakter diharapkan mampu menjadi alternatif solusi berbagai persoalan tersebut. Melihat situasi dan kondisi saat ini yang dihadapi bangsa Indonesia, tampaknya pendidikan karakter perlu ditransformasikan sejak dini, yakni sejak anak usia dini.

Proses pendidikan karakter ini perlu diberikan secara holistic dan terus menerus dengan berbagai pendekatan yang sesuai dengan perkembangan usia dankonteks peserta didik sesuai dengan makna kurikulum berdiverifikasi.

Pendidikan karakter bagi peserta didik perlu didesain, diformulasikan dan dioperasionalkan melalui tarnsformasi budaya kehidupan sekolah. Untuk itu dirasa perlunya membangun wacana dan sistem pendidikan karakter yang sesuai dengan konteks sosial kultur Indonesia yang berbhineka tunggal ika. ${ }^{3}$

Berdasarkan penjelasan di atas, ada fokus yang menjadi perhatian baikpemerintah, masyarakat, keluarga

3 Undang-Undang No. 20 Tahun 2003, Sistem Pendidikan Nasional 
dan orang perorangan yakni pendidikan budi pekertiatau pendidikan karakter sudah saatnya dapat dilaksanakan di sekolah, baik dari SDsampai ke perguruan tinggi.Aspek budi pekerti atau karakter sebagaimana yangdirumuskan dalam tujuan pendidikan nasional dan harapan masyarakat dapat berwujudsebagai perilaku peserta didik pada semua jeqiang dan jenis pendidikan.

Searah dengan tujuan tersebut, maka pendidikan karakter atau budi pekerti bertujuan untuk memfasilitasi siswa agar mampu menggunakan pengetahuan, mengkaji dan mengimplementasi serta mempersonalisasi nilai, mengembangkan keterampilan sosial yang memungkinkan tumbuh dan berkembangrya akhlak muliadalam diri siswa serta mewujudkannya dalam perilaku seharihari, dalam berbagaikonteks sosial budaya.

Untuk mencapai tujuan tersebut, maka secara kelembagaan, sekolah perlumerumuskan visi, misi, strategi, program dan kegiatan operasional yang memungkinkan sekolah dapat menggerakkan seluruh komponen dalam upaya melaksanakan pendidikan karakter atau budi pekerti sebaik-baiknya.

Ada empat dasar strategi yang dirumuskan secara komprehensip yaitu:

\section{Penciptaan suasana yang kondusif untuk pengalaman pembinaan nilai budipekerti}

Penciptaan suasana kondusif untuk pengamalan nilai budi pekerti merupakan penjabaran dari program sekolah.Program sekolah tersebut harusmengacu pada visi, misi, strategi, program dan kegiatan yang dijiwai nilai-nilaibudi pekerti dalam rangka mewujudkan tujuan pendidikan nasional. Dalam perumusan visi dan misi, sekolah harus secara eksplisit mencantumkan nilai-nilai budi pekerti luhur/karakter yang secara konsisten dijabarkan dalam strategi, program/ kegiatan sekolah baik intra maupun ekstrakurikuler. Visi dan misi sekolah merupakan komitmen seluruh jajaran/unsur yang terkait untuk mencapai tujuan pendidikan. ${ }^{4}$

\section{Integrasi budi pekerti pada mata pelajaran tertentu}

Secara teknis integrasi nilai budi pekerti terlihat pada pokok bahasan/sub pokok bahasan dari setiap mata pelajaran, terutama pada mata pelajaranpendidikan agama PKN dan bahasa Indonesia.Strategi nilai budi pekerti padamata pelajaran tersebut dapat dilakukan bila materi dari suatu mata pelajaranmendukung penanaman nilai budi pekerti/karakter, materi dari suatu mata pelajaran mengandung muatan 'bertentangan' dengan nilai budi pekerti. Penyajianmateri tersebut harus diluruskan sesuai dengan nilai budi pekerti, artinya guruharus mengoreksi jangan sampai ada materi pembelajaran yang bertentangandengan nilai-nilai budi pekerti. ${ }^{5}$

\section{Pendidikan budi pekerti melalui kegiatan ekstrakurikuler}

Pendidikan budi pekerti sebagai pendidikan internalisasi nilai dan sekaligus mempraktekkannya dalam kehidupan sehari-hari, maka kegiatanekstrakurikuler merupakan wahana yang cukup terbuka untuk menanamkanpendidikan budi pekerti. Dalam kaitan ini kiranya perlu dipahami bahwa : (1) nilaibudi pekerti ditanamkan melalui kegiatan remedial/perbaikan dari encichmentteaching oleh guru masingmasing. (2) nilai budi pekerti dapat efektif ditanamkanmelalui kegiatan tertentu seperti PMR, pramuka, upacara bendera,

4 SJJ.Drost, 2006, dari Kurikulum Bertujuan Kompetensi sampai Manajemen Berbasis Sekolah, Esai-esai Pendidikan Penerbit

5 Direktorat Pendidikan Dasar dan Menengah. Depdiknas RI, 2002. Pedoman Pendidikan Budi Pekerti. 
Olahraga.OSIS, kegiatan hari-hari besar nasional dan keagamaan. ${ }^{6}$

\section{Peningkatan kerjasama sekolah orang tua dan masyarakat}

Penyamaan persepsi penting dilakukan terutama dalam penyamaan persepsi tentang pentingnya pendidikan budi pekerti, dan berfungsinya pembinaanpendidikan budi pekerti di rumah, keluarga dan di masyarakat, orang tua danmasyarakat dapat membantu dalam pelaksanaan progrirm sekolah antara lain,memberi saran/masukkan dalam penyusunan aturan tata tertib sekolah, memberibantuan dalam memenuhi kebutuhan fasilitas sarana prasarana sekolah. ${ }^{7}$

Dari uraian di atas, jelaslah bahwa pendidikan karakter atau pendidikanbudi pekerti merupakan bagian integral dalam sistem pendidikan nasional yangsecara substansi dan praktis terintegrasi ke dalam mata pelajaran lain yang relevandan iklim sosial budaya sekolah. Oleh karena itu, keterlibatan seluruh komponenpenyelenggara pendidikan menjadi suatu keharusan sesuai dengan fungsi dantugas masing-masing.

\section{Kesimpulan}

Pendidikan karakter sangat penting artinya dilakukan oleh guru di sekolah,karena dapat membawa dampak positif bagi siswa itu sendiri.Nilai-nilai budi pekertidewasa ini khususnya di lingkungan sekolah bagi siswa sudah mulai merosot,akibatpengaruh arus informasi dan globalisasi, oleh sebab itu pihak sekolah harusmemprogramkan kegiatan pendidikan karakter secara berkelanjutan dan terusmenerus.Dengan kegiatan pendidikan karalcter atau budi

6 SJJ.Drost, 2006, dari Kurikulum Bertujuan Kompetensi sampai Manajemen Berbasis Sekolah, Esai-esai Pendidikan Penerbit Kompas, Jakarta.

${ }^{7}$ Dirjen Pendidikan Kemendiknas RI, 2010. Pendidikan Karakter. pekerti biasanya dimaksudmenanamkan nilai-nilai ke dalam budi orang.Sekolah merupakan kebersamaanbersemuka tempat hubungan personal otentik antara para pengajar dan para pelajardapat berkembang.Inilah ciri-ciri pembelajaran yang sekarang dikembangkan.Sekolah sebagai lembaga pembelajaran menanamkan nilai-nilai, membentuk manusiayang berkarakter dan berbudi luhur lewat mengajar. Program pendidikan karakter akanberhasil di sekolah, apabila semua personal di sekolah dapat bekerjasama dengan orang tua siswa, sehingga tujuan pendidikan yang diharapkan oleh bangsa ini benarbenar dapat dirasakan, dan dapat menyentuh nilai-nilai positif dari anak bangsa yangdiharapkan bersama.

\section{Daftar Pustaka}

Dirjen Pendidikan Kemendiknas RI, 2010. Pendidikan Karakter.

Direktorat Pendidikan Dasar dan Menengah. Depdiknas RI, 2002. Pedoman Pendidikan Budi Pekerti.

2001. Pendidikan berwawasan Keagamaan.

SJJ.Drost, 2006, dari Kurikulum Bertujuan Kompetensi sampai Manajemen Berbasis Sekolah, Esai-esai Pendidikan Penerbit Kompas, Jakarta.

Undang-Undang No. 20 Tahun 2003, Sistem Pendidikan Nasional 